\title{
Health and social care leaders' self-rated competence and learning needs in small and medium-sized enterprises
}

\author{
Mari Helena Salminen-Tuomaala, Kirsi Paavola, Paula Paussu \\ School of Health Care and Social Work, Seinäjoki University of Applied Sciences, Finland
}

Received: December 31, 2018

Accepted: February 19, 2019

Online Published: February 27, 2019

DOI: $10.5430 /$ cns.v7n2p62

URL: https://doi.org/10.5430/cns.v7n2p62

\begin{abstract}
Objective: The study is a descriptive survey based on quantitative and qualitative data. Its purpose is to describe leaders' self-assessed competence and learning needs in small and medium-sized health and social care enterprises as part of a larger research and development project in Finland. The information produced will be used in planning a simulation-based coaching intervention. The project partners are a health technology enterprise and two educational institutions.

Methods: Data were collected in late 2017 from 23 leaders of 20 enterprises using an internet-based questionnaire. The quantitative data were analyzed using SPSS for Windows and the qualitative data using inductive content analysis.

Results: The leaders felt confident about their ability to organize day-to-day activities, but reported learning needs related to interaction and entrepreneurship. Training was required in supporting staff in challenging situations, in understanding group dynamics and in developing dialogic interaction and emotional intelligence. The leaders were interested in learning how to market their services and improve the competitiveness of their enterprise with help of digitalization and networking, and how to prepare for the reform of health and social services. Most leaders were involved in practical care work and reported a need to update their clinical skills.

Conclusions: Increasing self-management contents and fostering an entrepreneurial attitude in nursing and social work curricula may provide one answer to the learning needs reported in this study. Simulation-based education can provide an effective learning environment for both students and professionals in health and social services.
\end{abstract}

Key Words: Competence, Learning need, Small and medium-sized enterprises, Quantitative, Qualitative, Simulation

\section{INTRODUCTION}

Small and medium-sized enterprises (SMEs, maximum net turnover 50 million euro, maximum staff headcount 250$)^{[1]}$ involved in the health and social care industry face multiple challenges today. They struggle to compete with larger organizations and to deal with the rapid restructuring of health and social care services. Continuous development of staff and leadership/management competence is essential, if the SMEs wish to maintain and improve their competitiveness. ${ }^{[2]}$

Like other companies and organizations, SMEs encounter increasing competence requirements in an environment, where knowledge becomes obsolete and technology advances at rapid rate. At the same time, the share of people with a combination health and social problems or dysfunction is

\footnotetext{
*Correspondence: Mari Helena Salminen-Tuomaala; Email: mari.salminen-tuomaala@ @eamk.fi; Address: School of Health Care and Social Work, Seinäjoki University of Applied Sciences, Finland.
} 
increasing, which is greatly due to a demographic change. As in many western industrialized countries, the population is ageing in Finland, where this research was conducted. ${ }^{[3]}$ The recognized need for child protection services has also increased in the past decade, as have mental health diagnoses in people of all ages. New tools and training are required to identify and intervene with child abuse and neglect. ${ }^{[4-6]}$ In addition, entire health and social systems repeatedly seem to undergo major reforms. ${ }^{[3,7,8]}$ It has been recommended that SMES should collaborate with educational organizations in anticipation of changing staff competence requirements. ${ }^{[7,9]}$

Much of the earlier research on human resources management and competence development has been conducted with larger organizations, and less attention has been paid to the study of competence development as part of business operations in SMEs. The development activity in SMEs is more often short term, because these companies are more vulnerable to market insecurities compared to larger organizations. ${ }^{[10]}$

\section{BACKGROUND}

\subsection{Terminology}

The leader's competence has been defined as a set of knowledge, skills, attitudes, experiences and contacts, which enable them to function across a variety of situations. ${ }^{[11]}$ It has also been pointed out that both motivation and commitment to company values and objectives are necessary for the continuous development of competence. ${ }^{[12]}$ Leaders are expected to possess both an understanding of the "substance" of the work and generic or meta-skills. ${ }^{[13]}$ In companies offering health services, leaders with expert knowledge of care and nursing can best plan and organize client care ${ }^{[14,15]}$ but it is often suggested that the world of work will increasingly require generic skills as well. ${ }^{[7,9]}$ Competence can be thought to be contextual in nature. In other words, it evolves in a community, where it is gradually constructed in interaction between professionals. ${ }^{[16]}$

A distinction is commonly made between management and leadership. For example, management is thought to refer to facilitation of daily routines or processes, whereas leadership is connected with change, direction and the ability to lead people. ${ }^{[17]}$ Although elements of both management and leadership are very much present in this paper, the two terms were not separately mentioned in the questionnaire used in this study or in the accompanying letter of explanation. This is simply due to the fact that the Finnish language does not contain two separate words for leadership and management, but a single term that encompasses both. In this article, both terms, leadership and management, are used with the awareness that both are essential elements of leaders' work in
SMEs. The target group members are referred to as leaders.

The term competency - intellectual, managerial, social and emotional capability ${ }^{[18]}$ - was not used in the questionnaire, either, because the term has not been translated into Finnish. The terms competence and skill were employed in the questionnaire instead. Competency is, however, referred to in the article, for example in the context of core competencies specific to particular work in a particular situation, and generic working life competencies common to all organizations. ${ }^{[19]}$

\subsection{Leaders' double role in SMEs}

As is common in small and medium-sized enterprises in the health and social sector in Finland, almost all leaders in this study had a double role in the company. Besides leadership and management duties, they participated in practical care work in one or two shifts. This means that in addition to management and leadership competence, they must have had a nursing or social work qualification and possessed sound practical competence required in health and/or social services.

In Finland, an increasing number of leaders with a nursing background in SMES have acquired a Bachelor degree in nursing, for which minimum professional competence standards have been defined in compliance with the European Union directive EU/2013/55. Today's nursing education aims at preparing professionals, who are competent not only in ethical and safe client-centered care, clinical nursing and promotion of health and functional capacity, but also in leadership and entrepreneurship, education and teaching, evidence-based practice and decision making. ${ }^{[20]}$ Similarly, an increasing number of professionals working in social services, for example in child protection or with intellectually disabled clients, have a Bachelor or Master degree in social services, which includes a moderate amount of leadership and management studies. ${ }^{[21]}$

Various lists of essential leadership and/or management competencies have been proposed for leaders working in health and social services. For example, it has been suggested that in 2020, nurse leaders should possess a global perspective, technology skills, expert decision-making skills and an ability to create a safe, high quality organization culture. They should also be highly competent in collaboration and team building and in balancing authenticity and performance expectations. All this must take place in a healthcare system, whose main qualities involve change, even chaos, so an ability to envision and adapt to the system is essential. ${ }^{[15]}$

The same competencies, networking and collaboration, technical skills and evidence-based decision-making are mentioned by another researcher as important areas of future 
leadership and management in health services. In addition, this investigator emphasizes financial management skills, the growing role of knowledge management related to the increasing volume of expertise in organizations, and the management of larger wholes. ${ }^{[22]}$

Another example of research on desirable competencies of leaders in the health and social services lists substance knowledge, business skills, organizational competence, social and decision-making, and adds the ability to approach change in a creative and innovative manner. ${ }^{[23]}$ Good mentoring skills are also often mentioned in literature on leaders' competence requirements. ${ }^{[19,24]}$ Finally, successful leaders have been found to possess good intrapersonal ${ }^{[19]}$ or selfmanagement skills. ${ }^{[25]}$ They are capable of realistic and honest self-evaluation and professional development based on generalized self-efficacy. ${ }^{[19,25]}$

To repeat, leaders in SMEs often have a double role as nurses/carers and leaders and they are expected to possess the respective competencies. Much of the competence in these two areas seems overlapping, especially as regards generic competencies. It would also seem that a generic competency, for example interaction, could be considered a core competency and a central tool both in management and in health and social care. ${ }^{[26]}$

The next sections discuss areas considered important for leaders in the SMEs in health and social services in the context of this research project: first, dialogic leadership and interaction as a central concept related to dialogic leadership (2.3) and secondly, operational management and entrepreneurship (2.4).

\subsection{Dialogic leadership and interaction}

In recent years, many researchers have advocated the principles of dialogic leadership as a response to current challenges in the health and social services. ${ }^{[27]}$ Dialogic leadership is seen to be characterized by genuine encounters between people, in which all parties' individuality is taken into consideration and respected. The core of dialogic leadership lies in empathy and understanding of another person. It requires that leaders are profoundly aware of their personal leadership style and able to adapt their style to meet the needs of their staff. $^{[28]}$

Interaction and promotion of teamwork can be said to permeate leadership. Dialogic leadership is constructed in an interaction process between the leader and staff and it is also affected by each particular context. ${ }^{[27]}$ As one researcher put it, rather than a position of authority, leadership is a dynamic and emergent interactive process. ${ }^{[26]}$ The leaders' role is to activate and encourage, and to seek to openly and naturally encounter situations arising in the workplace. This approach can create an atmosphere that is open to staff contributions. ${ }^{[28]}$ Self-awareness (an accurate understanding of one's weak and strong points) and emotional intelligence (ability to express and understand emotions in social interaction) are essential to good effective visionary leaders, who know how to listen and encourage others. ${ }^{[26]}$

Mentoring skills are another competency that can be mentioned in this context as desirable attributes of leaders. Mentoring, which comes close to consultation and guidance, can be seen as an informal process of providing knowledge, social capital and psychosocial support to the less experienced members of the working community. Good mentors can facilitate development in workplaces by supporting their teams. ${ }^{[24]}$

As a last remark to this section: it has been suggested that leading people by enhancing their competence and commitment will be the key competitive factor for businesses in future. ${ }^{[11]}$ Dialogic leadership is believed to be useful in this respect by its potential to stimulate creativity and competence management ${ }^{[27,29]}$ and to facilitate staff's day-to-day coping. ${ }^{[27,30]}$

\subsection{Operational management and entrepreneurship}

In practice, much of the leaders' work consists of organizing day-to-day activities, ${ }^{[27,30]}$ referred to as operational management in this paper. The terms business skills or technical competencies have sometimes been used in the same sense. Operational management involves planning, monitoring and evaluating performance, strategies and budgets, and organizing day-to-day activities such as meetings and reports. ${ }^{[19]}$ This management task also has to do with ensuring that various contextual characteristics, for example the physical working environment, safety, objectives, rewards and time management, are appropriately addressed. ${ }^{[31]}$ In other words, leaders are responsible for creating well structured care environments and for ensuring that the organizational context supports the work of the personnel. ${ }^{[26]}$ Well-organized work has been found to promote staff members' wellbeing. ${ }^{[32]}$ Contextual characteristics can be supportive for enhancing creativity in the workplace. ${ }^{[31]}$

Decision-making has an essential role in day-to-day management tasks. Leaders must be able to make prompt decisions without losing sight of the long-term objectives. The work requires thinking skills, production of insights and careful analysis of client needs. ${ }^{[11]}$ One must also bear in mind that in today's environment of increasing interdisciplinary or multiprofessional collaboration, ${ }^{[7,9]}$ decisions are not made in isolation. It could be added that in the context of decision- 
making, as in leadership in general, the ability to learn and develop could be considered a core competency. ${ }^{[33]}$

Finally, entrepreneurship is a relevant concept in this study, in which most target group members were entrepreneurs in the health and social sector. Even those leaders, who do not represent external entrepreneurship in a form of professional activity, can benefit from an entrepreneurial mindset and behavior. ${ }^{[34]}$ Entrepreneurship can be seen as a practice of creating something new, assuming responsibility, taking things forward and reaching results, despite having to bear uncertainty. ${ }^{[35]}$ Aspiring entrepreneurs must be able to assess the market and needs for services, seek funding, recruit workers, forge business plans and create networks. Marketing competency is also required to ensure the company's competitiveness and attractiveness. ${ }^{[36]}$ Successful entrepreneurs have visionary skills, which means that they are capable of foresight and able to create visions and processes that engage people in change. ${ }^{[37]}$

\section{METHODS}

\subsection{Study purpose and aim}

This study is a descriptive survey based on quantitative and qualitative data. Its purpose is to describe leaders self-assessed competence and learning needs in small and medium-sized health and social care enterprises in Finland. The study precedes leaders' participation in a simulationbased coaching intervention. This assessment is part of a larger research and development project, and its aim is to provide information that will be used in planning the multiprofessional, simulation-based coaching program. The project partners are experts from a health technology enterprise and teaching staff from two educational institutions in the health and social field.

\subsection{Research questions}

The research questions are:

- How do leaders in small and medium-sized health and social care enterprises rate their leadership competence?

- How do leaders in small and medium-sized health and social care enterprises rate their operational management competence?

- How do leaders in small and medium-sized health and social care enterprises rate their entrepreneurship competence?

- What are the learning needs of leaders in small and medium-sized health and social care enterprises?

\subsection{Target group and data collection}

The target group of this research consists of leaders in twenty small and medium-sized enterprises in Finland, which provide housing, support, care and child protection services for the aged, the disabled, children and people with mental health disorders. The survey conducted with the leaders was part of a more extensive survey carried out with staff members in the same companies in a region with a population of 200,000. Data were collected during October and November 2017 using an internet-based Webropol questionnaire.

As is common in Finnish SMEs operating in the health and social sector, the leaders were mostly registered nurses with a Bachelor degree or held a Bachelor degree in social services. Besides leadership and management duties, most of them participated in practical care work in one or two shifts. The majority of the leaders were entrepreneurs, that is principal owners responsible for managing the finances of the company. Eight companies were so-called micro enterprises (under 10 employees), thirteen were small (10-50 employees) and two were medium-sized (51-80 employees).

The questionnaire, developed for the purposes of this research and development project, was based on a systematic literature review and on a preliminary competence assessment conducted with SMEs earlier in 2017. The leaders' questionnaire contained 10 Likert scale items covering the following competence areas: 1) organizing day-to-day activities; 2) decision-making skills; 3) conducting discussions with staff members; 4) mentoring skills; 5) encouraging staff members to deal with challenging tasks; 6) entrepreneurship skills; 7) marketing the enterprise; 8) improving the competitiveness of the enterprise; 9) improving the attractiveness of the enterprise; and 10) identification of future challenges. The first two areas (1-2) represent operational management, the following three areas (3-5) cover leadership, and the remaining areas (6-10) represent entrepreneurship. Respondents were instructed to rate their competence by choosing one of the following options: 1) very good skills; 2) fairly good skills; 3) neither good nor poor skills; 4) fairly poor skills; and 5) very poor skills.

Besides the quantitative items, the questionnaire included qualitative questions, whose purpose was to explore respondents' individual simulation-based learning needs and the enterprise's needs for collaborative simulation-based learning. Respondents' age, sex, educational background, qualification and professional position were also requested in the questionnaire.

The questionnaire was pretested by 14 persons, most of whom represented project partners. Together with two project steer group members and two persons from SMEs, 
they declared that the questionnaire was easily comprehensible and fit for purpose. The project partners used a Moodle environment for communication with the target group. Potential respondents also received an invitation to participate and an accompanying letter of explanation via e-mail. The letter contained a link to the questionnaire and information about the voluntary and anonymous nature of the study.

\subsection{Data analysis}

One of the authors of this article is responsible for the analysis, but all investigators offered their comments on the results. ${ }^{[38]}$ The quantitative data were exported to the Excel spreadsheet program and from there to SPSS for Windows 23 for analysis. The qualitative data underwent an inductive content analysis. Frequency and percentage distributions, and measures of central tendency were used to gain information about the data. Because of the limited sample and risk of respondents becoming identifiable, it was decided that the results should not be compared by age, sex, education or professional position.

The qualitative data, which amounted to 10 pages (Times New Roman, font size 12, spacing 1.5), were analyzed using inductive content analysis. After reading the data several times, phrases which appeared to answer the research question, were picked out, saved and rewritten as reduced expressions in Word files. Categories were created of items with similar meanings, named and further organized into higher order categories and, finally collapsed into a main category. During this process, the investigator repeatedly returned to the original material.

\subsection{Ethics, validity and reliability}

An effort was made during the research process to observe good scientific practice, honesty and precision. ${ }^{[39]}$ The choice of topic can be regarded as ethically justifiable, because there is little previous research on leaders' competence in SMEs in the health and social sector. The investigators followed the guidelines on responsible conduct of research and the ethical principles of research in the humanities and social and behavioral sciences, as outlined by the Finnish National Board on Research Integrity and the Helsinki Declaration. ${ }^{[40,41]}$ Participation was voluntary, based on informed consent. Respondents received the relevant information via e-mail and the Moodle platform. An anonymous Webropol survey was used to ensure that both individual participants and their organizations remained unidentifiable. ${ }^{[42]}$

The reliability and content validity of the quantitative items were discussed among the research team and pre-tested with 14 persons. The pre-testers found the questions clear and easy to understand. No obvious confounding variables were dis- covered and the questionnaire was deemed to measure what is should measure, or to be internally valid. The internetbased survey tool employed was useful in collecting an adequate amount of data, and achieving a very high response rate $(96 \%)$, which increases the reliability of the study. ${ }^{[43]}$ On the other hand, the limited sample size decreases the generalizability or external validity of the study. Although representative of one region in Finland, the results can be only considered indicative. ${ }^{[42]}$

The qualitative material was rich and saturation was reached. The analysis is supported by direct quotes from participants to increase the credibility and confirmability of the research. Confirmability is further enhanced by careful description of the research process. ${ }^{[44]}$ The investigators also stopped to consider reflexivity, or how their background and managerial experience in specialized medical services might have influenced the research process and analysis. Their pre-understanding may have facilitated the analysis, but an effort was made to reach a balance between pre-conceived ideas and data-driven analysis. ${ }^{[38]}$ Finally, the investigators assessed the transferability of the results. ${ }^{[45]}$ The results can be used nationally when planning training interventions for leaders of SMEs in the health and social sectors.

\section{RESUlts}

\subsection{Demographic data}

As mentioned above, this assessment is part of a larger research and development project. Of all the participants $(\mathrm{n}=$ $125)$ in the project with SMEs, $18 \%(\mathrm{n}=23)$ were leaders in 20 enterprises. They were registered nurses with a Bachelor or Master degree, or they held a Master degree in health sciences or a Bachelor degree in social services. Respondents' age range was 27-65 years.

Almost all leaders (19) were nurses. There were only 2 leaders with a social worker education and 2 leaders, who were elderly care experts.

\subsection{Leaders' self-rated leadership competence}

The leaders in this study reported great confidence in their mentoring skills; the majority or $80 \%$ rated their skills as very good and $20 \%$ as fairly good. In contrast, however, encouraging staff members to deal with challenging tasks was considered demanding. Most respondents, $60 \%$, assessed their skills as fairly poor, and only $40 \%$ reported fairly good skills. There was great variation in responses to the item on conducting discussions with staff members; half of the respondents rated their skills as very good, $25 \%$ as fairly poor and $25 \%$ as very poor. 
4.3 Leaders' self-rated operational management competence

The leaders felt that they possessed good skills in organizing day-to-day activities. The results were: very good skills $80 \%$; fairly good skills $20 \%$. None of the respondents rated their organization skills as poor. Some variation was discovered in respondents' ratings concerning their decision-making skills. The great majority, $75 \%$, reported very good decisionmaking skills, but $15 \%$ selected the option fairly poor skills and $10 \%$ the option very good skills.

\subsection{Leaders' self-rated entrepreneurship competence}

Entrepreneurship skills were considered a challenge; $40 \%$ of the respondents said that their skills were fairly poor and $20 \%$ that their skills were very poor. The remaining $40 \%$ were divided between very good (20\%) and fairly good (20\%). Most respondents were also insecure about their marketing skills. Very poor skills were reported by $60 \%$ and rather poor skills by $20 \%$ of the leaders. Only $20 \%$ announced that their marketing skills were fairly good. When inquired about their ability to improve the competitiveness of the enterprise in today's society, the leaders' responses varied a great deal: fairly good skills $42 \%$; neither good nor poor skills $38 \%$; fairly poor skills $12 \%$ and very good skills $7 \%$. Similar results were obtained for leaders' self-rated ability to improve the attractiveness of the enterprise. Here, too, most respondents found their skills either fairly good (40\%) or neither good nor poor (37\%). The remaining respondents reported fairly poor $(13 \%)$ or very good skills $(9 \%)$. Finally, the results for the identification of future challenges were close to those for improving the competitiveness and attractiveness of the enterprise: neither good nor poor skills $42 \%$; fairly good skills $40 \%$; fairly poor skills $10 \%$; and very good skills $6 \%$.

\subsection{Leaders' self-reported learning needs}

As a response to the qualitative questions, the leaders in this study reported learning needs related to interaction, networking, marketing, management of clinical situations and the imminent reform of the social and healthcare system.

\subsubsection{Improving interaction}

Respondents stressed their need to develop teamwork skills. They said, for example, that they required training in understanding group dynamics and in developing dialogic interaction and emotional intelligence. Arrival of new employees was mentioned as a demanding situation. As one respondent said, the challenge is "how to bring a new, shy person into the group?" (nurse)

Leaders also felt the need to improve their interaction skills to be better prepared to deal with overbearing and strong-willed employees, who sought to dominate other staff members. Respondents explained that they required coaching in how to recognize people's temperaments. They also wished for situation awareness training, not only for themselves, but for the entire staff. They said, for example:

"How to interfere, when one person is always talking and does not give space to other people?" (social worker)

"How to recognize the situation and interfere discreetly, so that nobody gets insulted?" (nurse)

\subsubsection{Improving networking}

Leaders also felt that they would benefit from training in networking and benchmarking. It was mentioned that keeping up with larger organization was difficult for SMEs, unless an effort was made to keep abreast of the latest clinical interventions and client service developments. In respondents' own words:

"The distances are long here in the countryside, so it would be good if we could build a network with other SMEs and share our competence." (social worker)

"Concrete multiprofessional networking, how can that take place?" (nurse)

"Networking could help us be better aware of what kind of services our clients expect." (nurse)

\subsubsection{Improving marketing}

Leaders found that marketing competence was of growing importance. They referred not only to their personal but also to the whole enterprise's marketing competence. Use of social media for marketing was also mentioned as a learning need. Respondents felt that they lacked concrete marketing skills required in improving the company's competitiveness. Only one of the leaders in this study had undergone some formal training in marketing. Below are some of the comments made by the respondents.

"I should learn marketing, my background is being a hardworking laborer. I do not know how to praise my skills, I just humbly do my thing and give in." (nurse)

"Social media skills would be important for marketing." (nurse)

"Digi skills and hyping up myself and my skills, if only I knew how to." (nurse)

\subsubsection{Improving the management of clinical situations}

Most leaders in this study were involved in practical client care, so they also reported learning needs related to new interventions in the management of clinical situations. They said that they would find it useful to have simulation-based training in how to deal with acute situations in old people's 
care, mental health work and child protection. Clients live to an older age, which brings new challenges for health and social care personnel. Education is required on how to support clients in the last part of their life span and how to implement best possible end-of-life care. Respondents said, for example:

"I need training in first aid and resuscitation to help old clients with acute chest pain." (nurse)

"Knowledge about what an old person's confusion might be due to." (nurse)

"The whole enterprise needs knowledge about acute situations, not just the leader." (nurse)

“Clinical competence for end-of-life care.” (nurse)

\subsubsection{Preparing for the reform of the health and social care system}

The imminent restructuring of the entire system of health care and social system in Finland, known by the abbreviation SOTE, seemed daunting to the leaders in this study. Respondents felt that they had little knowledge about the reform, and the term SOTE alone caused anxiety among them. Still, they believed that it was necessary to increase knowledge about the reform and about how intersectoral collaboration might be organized in future. Leaders anticipated that the reform and the changing operating environment would increase the need for strategic management, knowledge management and digital skills. According to respondents, visionaries and business experts would be required in the management of SMEs in future. They also felt that the increasingly multicultural and international society would require constant learning and updating of language skills and cultural knowledge. To cite the respondents:

"What will that SOTE bring, we need some explanation in plain language." (nurse)

"Sote and distance counseling, what will they mean in the day-to-day life in SMEs and how will our clients cope? (social worker)

"SOTE and multiculturalism mean that an Islamic grandma needs to be treated and cared for in a different way than a Finnish grandma, you also need international competence.' (nurse)

\section{Discussion}

The study reveals learning needs of leaders in small and medium-sized enterprises in the health and social sector. As is common in such enterprises, the leaders in this study had a double role, working as carers/nurses and leaders simultaneously. The majority were entrepreneurs.
The leaders felt confident about their ability to organize dayto-day activities, but reported learning needs related to interaction and entrepreneurship. Although they rated their mentoring skills as very good or good, they felt that they required training in supporting staff in challenging situations, in understanding group dynamics and in developing dialogic interaction and emotional intelligence. The importance of consciously developing emotional intelligence and situational judgment, for example by engaging in self-assessment and self-reflection activities, has been emphasized in earlier research. ${ }^{[9,26]}$ A practical interaction situation, for example a discussion between a leader and a staff member, could effectively be practiced with help of simulation. There is research evidence that simulation-based coaching is suitable for learning interaction, team work and leadership skills, including dialogic leadership. ${ }^{[27,46]}$

The leaders in this study were particularly aware of their need for entrepreneurship training, especially on how to market their services and improve the competitiveness of their enterprise with help of digitalization and networking. Marketing requires interaction skills, besides being built on successful client analysis, pricing and feedback mechanisms. ${ }^{[47,48]}$ Much of today's marketing occurs online, but a recent report published in Finland reveals that leaders in SMEs still largely lack the routines, training or attitudes necessary for a successful digitalization process. A digital leap is not possible, unless old practices are questioned and new solutions sought actively. One of the benefits of digital services is their potential in increasing networking. ${ }^{[49]}$

Foresight skills, or identification of future challenges, are essential for leaders and entrepreneurs and visionary skills can be regarded as one of the key leadership attributes. ${ }^{[26]}$ As an example of a current challenge, the leaders in this study reported the need to prepare for the imminent reform of the social and health service system. Insecurity still prevails among staff in SMES about the effect of restructuring on their work. In this situation, leaders would benefit from an ability to create and communicate a vision to guide the transition. This would involve challenging the existing state of affairs, listening and encouraging staff, and engaging in a shared vision. ${ }^{[26]}$

The leaders in this study had no formal entrepreneurial and managerial education. Their nursing or social work degree contained few courses in management or entrepreneurship, and it may not be realistic to expect the number of such courses to significantly increase at the cost of other topics in the future. Integrating self-management contents or an entrepreneurial attitude into curricula, however, is a more feasible option. In any case, professional development and 
training are required. The leaders in this study will participate in a simulation-based coaching intervention tailored to meet their needs.

\section{Conclusion}

Leaders working in small and medium-sized enterprises in the health and social sector commonly lack formal education in management and entrepreneurship. As participants in this study, they may possess good organization and day-today management skills, but would benefit from training on entrepreneurship, marketing, digitalization and challenging interaction situations. Increasing self-management contents and fostering an entrepreneurial attitude in nursing and social work curricula may provide one answer, and simulationbased education can provide an effective learning environment for both students and professionals. The results of this study can be useful for national and international teams planning nursing and social work curricula or professional development programs for leaders of small and medium-sized enterprises.

\section{CONFLiCTS OF INTEREST Disclosure}

The authors declare they have no conflicts of interest.

\section{REFERENCES}

[1] Directorate-General for Enterprise and Industry (European Commission). Evaluation of the SME definition. 2014. Available from: https://publications.europa.eu/en/publicatio n-detail/-/publication/5849c2fe-dcd9-410e-af37-1d3 75088 e886

[2] Henttonen E. Osaamisen kehittäminen pk-yrityksissä. ESRprojektien hyvät käytännöt. [Competence development in SMEs. Good practices in ESR projects.] Euroopan sosiaalirahasto [European Social Fund]. 2002-2006. Helsinki: Oy Edita Ab; 2002. Available from: http://www.rakennerahastot.fi/vanhat_sivut/ra kennerahastot/tiedostot/esr_julkaisut_2000_2006/07 _osaamisen_kehittaminen_pk-yrityksissa_esr-projekt ien_hyvat_kaytannot.pdf

[3] Tuomela K, Heikkilä K, Haapanen H, et al. Moniammatillinen oppiminen yhteistyöosaamisen edistäjänä terveydenhuollossa. [Multiprofessional learning in promoting cooperation skills in the health service.] Hoitotiede. 2017; 29(4): 264-75.

[4] Inkilä J, Helminen M, Aalto P, et al. Interprofessional collaboration with the family in child maltreatment situations. Journal of Nursing Science. 2016; 28(3): 204-16.

[5] Sanders T, Cobley C. Identifying non-accidental injury in children presenting to A \& E departments: An overview of the literature. Accid Emerg Nurs. 2005; 13: 130-6. PMid:15862987. https://doi.org/10.1016/j.aaen.2005.02.001

[6] Ziegler D, Sammut J, Piper A. Assessment and follow-up of suspected child abuse in preschool children with fractures seen in a general hospital emergency department. J Paediatr Child H. 2005; 41 : 251-5. PMid:15953323. https ://doi.org/10.1111/j.1440-1 754.2005.00605. $\mathrm{x}$

[7] Manka ML. Tiikerinloikka työniloon ja menestykseen. [Tiger's leap for job satisfaction and success.] Helsinki: Talentum; 2010.

[8] Weller JM, Barrow M, Gasquoine S. Interprofessional collaboration among junior doctors and nurses in the hospital setting. Med Educ. 2011; 45(5): 478-87. PMid:21414024. https ://doi .org/10.111 $1 / j .1365-2923.2010 .03919 . x$

[9] Rehn A. Johtajuuden ristiriidat.[Conflicts of management.] Jyväskylä: Docendo Oy; 2018.

[10] Kerr A, Mcdougall M. The Small Business of Developing People. International Small Business Journal: Researching Entrepreneurship. 1999; 17(2): 65-74. https://doi.org/10.1177\%2F0266242699 172004

Published by Sciedu Press
[11] Sydänmaanlakka P. Älykäs johtajuus. [Intelligent leadership.] Helsinki: Talentum Media Oy; 2009.

[12] Viitala R. Johda osaamista. Osaamisen johtaminen teoriasta käytäntöön. [Competence management from theory to practice.] Keuruu: Otavan kirjapaino; 2005.

[13] Tuomi L, Sumkin T. Osaamisen ja työn johtaminen. [Management of competence and work.] Helsinki: Sanoma Pro Oy; 2012.

[14] Surakka T. Osastonhoitajien työn muuttuminen 1990-luvulta 2000luvulle. Tampereen yliopisto. [Head nurse's work in the hospital environment in the 1990's and the 2000's. Doctoral dissertation.] University of Tampere; 2006. 200 p.

[15] Huston C. Preparing nurse leaders for 2020. J Nurs Manag. 2008; 16(8): 905-11. PMid:19094101. https://doi.org/10.1111/j. 1365-2834.2008.00942.x

[16] Collin K. Työssä oppiminen. [Learning at work]. In K. Collin \& S. Paloniemi (Eds.) Aikuiskasvatus tieteenä ja toimintakenttinä. [Adult education, science and practice] Jyväskylä: PS-Kustannus; 2007. 123-54 p.

[17] Limb M. How does leadership differ from management in medicine? BMJ. 2016; 352: i631. https://doi .org/10.1136/bmj . i631

[18] Singh Chouhan V, Srivastava S. Understanding competencies and competency modeling - a literature survey. IOSR-JBM. 2014 Jan. Available from: https://www.researchgate.net/publicati on/269791910_Understanding_Competencies_and_Compet ency_Modeling_-_A_Literature_Survey

[19] Asumeng M. Managerial competency models: a critical review and proposed holistic-domain model. Journal of Management Research. 2014; 6(4). https : //doi.org/10.5296/jmr.v6i4.5596

[20] Eriksson E, Korhonen T, Merasto M, et al. Sairaanhoitajan ammatillinen osaaminen. Sairaanhoitajakoulutuksen tulevaisuus -hanke. [The nurse's professional competence. The future of nursing education project.] Ammattikorkeakoulujen terveysalan verkosto ja Suomen sairaanhoitajaliitto ry. Porvoo: Bookwell Oy; 2015.

[21] Hattuniemi P. Sosionomien johtamisosaaminen. Erikoisosaamistarpeet nyt ja tulevaisuudessa. [The needs of Bachelors and Masters of social services concerning leadership expertise. Bachelor thesis.] Diaconia University of Applied Sciences; 2016. 82 p.

[22] Huttunen P. Hoitotyön johtamisosaaminen ja tulevaisuuden osaamishaasteet erikoissairaanhoidossa. [Nursing managerial competence in the specialized health care today and the future. Master thesis.] University of Eastern Finland; 2013. 45 p.

[23] Viitanen E, Kokkinen L, Konu A, et al. Johtajana sosiaali- ja terveydenhuollossa. [Being a manager in social and health ser- 
vices.]Kunnallisalan keittämissäätiön tutkimusjulkaisut nro 59. Vammalan kirjanpaino; 2007.

[24] Opetushallitus [Board of Education in Finland]. Mentorointi. Laadunhallinnan tuki. Menetelmiä ja työvälineitä. [Mentoring. Quality management support. Methods and tools.] Available from: https: //www.oph.fi/saadokset_ja_ohjeet/laadunhallinnan_t uki/wbl-toi/menetelmia_ja_tyovalineita/mentorointi

[25] Paasivaara L. Itsensä kokoinen johtaja - itsetuntemus työyhteisön voimavarana. [Being comfortable in the manager's shoes-selfawareness as a resource in the working community.] Helsinki: Kustannusosakeyhtiö Tammi; 2010.

[26] Henriksen J. An alternative approach to nurse manager leadership. Nurs Manag. 2016 Jan; 47(1): 53-5. PMid:26703360. https : //doi.org/10.1097/01. NUMA.0000475636.82881.75

[27] Syvänen S, Kasvio A, Loppela K, et al. Dialoginen johtaminen innovatiivisuuden tekijänä. [Dialogical leadership as a factor of innovativeness.] Helsinki: Työterveyslaitos; 2012.

[28] Nummelin T. Keskusteleva esimiestyö. Opitaan kokemuksesta. [Conversational leadership. Learning from experience.] Helsinki: WSOYpro; 2007.

[29] Isaacs WN. Dialogic Leadership. Systems Thinker. 1999; 10(1): 1-5.

[30] Syvänen S, Tikkamäki K, Loppela K, et al. Dialoginen johtaminen. Avain tuloksellisuuteen, työelämän laatuun ja innovatiivisuuteen. [Dialogic leadership. Key to productivity, quality of working life and innovation.] Tampere: Tampereen yliopistopaino Oy Juvenes Print; 2015.

[31] Shalley CE, Zhou J, Oldham GR. Effects of personal and contextual characteristics on creativity: where should we go from here? J Manage. 2004; 30: 933-58. https ://doi.org/10.1016/j.jm. 2004. 06.007

[32] Elo AL, Mattila P, Kylä-Setälä E, et al. Työyhteisön ja johtamisen kehittämisohjelman vaikutus työhyvinvointiin. Evaluaatiotutkimus kunta-alan teknisessä virastossa. [The effect of a working community and management development program on wellbeing at work. Evaluation study in municipal technical services.] Työ ja ihminen tutkimusraportti 26. Helsinki: Työterveyslaitos; 2004.

[33] Hätönen H. Osaamiskartoituksesta kehittämiseen II. [From a competence survey to competence development II.] Helsinki: EducaInstituutti Oy; 2011.

[34] Ristimäki K. [Etrepreneurship education.] Järvenpää: Yrityssanoma Oy; 2004.

[35] Lewis C, Malmgren P. The Leadership Lab. Understanding leadership in the 21st century. CPI Group Ltd, Croydon; 2018.

[36] Wilson A. Rising to the challenge of health care reform with entrepreneurial and intrapreneurial nursing initiatives. Online J Issues Nurs. 2012; 17(2): 5. PMid:22686113.
[37] Vanhamäki O. Strateginen kyvykkyys - mistä se on tehty? [Strategic capability-what is it made of?] 2018. Available from: https://ww w.balentor.fi/strateginen-kyvykkyys-mista-se-tehty

[38] Graneheim UH, Lundman B. Qualitative content analysis in nursing research: concepts, procedures and measures to achieve trustworthiness. Nurse Educ Today. 2004; 24(2): 105-12. PMid:14769454. https://doi.org/10.1016/j.nedt.2003.10.001

[39] Aho AL, Kylmä J. Sensitiivinen tutkimus hoitotieteessä: näkökohtia tutkimusprosessin eri vaiheissa. [Sensitive research in nursing science: perspectives throughout the research process.] Hoitotiede. 2012; 24(4): 271-80. Available from: http://urn.fi/URN: NBN : f $i$ :ELE-1580734

[40] TENK Finnish Advisory Board on Research Integrity Responsible conduct of research and procedures for handling allegations of misconduct in Finland 2012. Available from: http: //www.tenk.fi/ files/HTK_ohje_2013.pdf

[41] Helsinki Declaration World Medical Association Declaration of Helsinki - Ethical principles for medical research involving human subjects (1964), last amended in October 2013. Available from: https://www.wma.net/policies-post/wma-declaration -of-helsinki-ethical-principles-for-medical-resea rch-involving-human-subjects/

[42] Burns N, Grove S. The practice of nursing research. Appraisal, synthesis and generation of evidence. 6th ed. Missouri: Saunders Elsevier; 2009.

[43] Baruch Y, Holtom BC. Survey response rate levels and trends in organizational research. Hum Relat. 2008; 61(8): 1139-60. https : //doi.org/10.1177/0018726708094863

[44] Polit DF, Beck CT. Nursing Research: Generating and Assessing Evidence for Nursing Practice. 9th ed. Lippincott, Williams \& Wilkins, Philadelphia; 2012.

[45] Lincoln YS, Guba EG. Naturalistic inquiry. CA: Sage Publications. Newbury Park; 1985.

[46] Jacobs BL. Teaching and learning negotiation in a simulated environment. Wideren L J. 2008; 18: 91-112.

[47] Saarijärvi H. Customer value co-creation through reverse use of customer data. [Academic dissertation.] University of Tampere School of Management Finland; 2011. Available from: http://urn.fi/urn: isbn: 978-951-44-8595

[48] Rintamäki T. Managing customer value in retailing. An integrative perspective. Acta Universitatis Tamperensis 2152. University of Tampere School of Management Finland. Tampere University Press Tampere; 2016.

[49] Jungner M. Otetaan digiloikka! Suomi digikehityksen kärkeen. [Let us take a digi leap! Finland to the top of digital development.] Elinkeinoelämän keskusliitto. 2015. Available from: https://ek.fi/wp - content/uploads/Otetaan_digiloikka_net.pdf 